\title{
Reduced Formation of Hippuric Acid After Oral Benzoic Acid in Friedreich's Ataxia
}

\author{
A. BARBEAU, R. BOUCHARD (*), T. CLOUTIER, J.P. BOUCHARD (*)
}

SUMMARY: We have observed a markedly decreased formation of hippuric acid after benzoic acid load in patients with typical Friedreich's Ataxia compared to normal control subjects. Since there is evidence for normal or even enhanced tauro-conjugation in the bile of patients with this disease, with a decreased $G / T$ ratio, it is unlikely that co-factor or enzyme concentrations are the cause of this defect. We postulate decreased availability of the

RESUME: Nous avons observé une diminution significative de la formation d'acide hippurique après une surcharge en acide benzoique chez des patients avec ataxie de Friedreich comparés à des sujets témoins normaux. Etant donné qu'il existe des indices de l'existence d'une tauroconjugaison biliaire normale ou stimulée chez ces patients, accompagnée d'un rapport $G / T$ abaissé des conjugués biliaires, il nous semble que l'étiologie de ce phénomène ne réside pas au niveau des cofacteurs ou de la concentration de l'enzyme de conjugaison. Nous proposons qu'il existe enzyme for glycine conjugation either to bile acids in the usual situation or to benzoic acid in the artefactual test condition. This could be due to the enzyme's preference for an increased amount of taurine substrate in the liver. The relationship of this observation to the other biochemical changes observed in Friedreich's Ataxia must still be established.

plutôt une diminution dans la disponibilité de l'enzyme pour la conjugaison de la glycine, soit avec les acides biliaires dans la situation habituelle, soit avec l'acide benzoique dans les conditions expérimentales du test. Ceci pourrait être dû à la préférence (affinité?) marquée de l'enzyme pour une concentration augmentée du substrat taurine au niveau du foie. Le lien pouvant exister entre cette observation et les autres modifications biochimiques notées dans l'ataxie de Friedreich reste à démontrer.
From the Clinical Research Institute of Montreal and $\left({ }^{*}\right)$ l'Hôpital de l'Enfant-Jèsus, Québec.

Reprint requests for the complete supplement on Friedreich's Ataxia (Phase Three, Part Two) to: Prof Andre Barbeau, Clinical Research Institute of Montreal, 110 Pine Avenue West, Montreal, Quebec, Canada, H2W IR 7 .

\section{INTRODUCTION}

Previous studies from our group (Barbeau et al, 1976; Hamel et al, 1978) have indicated that some patients with Friedreich's Ataxia have elevated levels of unconjugated plasma bilirubin, indicating possible liver implication in the disease. This finding has been confirmed by Campanella et al, (1980) in Southern Italy but not by Walker et al, (1980) in England. One hypothesis presented (Morgan et al, 1979) involved the observed increased formation of erythrocyte protoporphyrins by these patients. A possible clue to this problem was recently fortuitously obtained while investigating the profile of $\alpha$-keto acids in blood and urine of patients with Friedreich's Ataxia (Bertrand et al, this issue, 1982). It was noticed that the urinary concentration of hippuric acid, a minor constituent in normal urines, was considerably decreased in ataxic patients (mean of $163.4 \mathrm{mg} / 1$ in patients versus mean of $298.5 \mathrm{mg} / 1$ in normal control subjects).

Hippuric acid is formed from the conjugation of benzoic acid with glycine in the liver. In 1936, Quick recommended the estimation of hippuric acid excreted in the urine after the ingestion of benzoic acid as a test of liver function. This test is probably the most practical to evaluate the ability of the liver to detoxify or conjugate, although it is rarely performed these days. We proposed to use this test to obtain some general information on the formation of hippuric acid in Friedreich's Ataxia, and possibly on the mechanisms of conjugation in that disorder.

\section{SUBJECTS AND METHODS}

Quick's test as modified by Weich- 
selbaum and Probstein (1938) was administered to 12 patients with typical Friedreich's Ataxia responding to the criteria set by Geoffroy et al, (1976) and to 8 normal control subjects. Four of the patients were from the Rimouski isolate previously described (Bouchard et al, 1979), while the others were from Montreal. There were 6 men and 6 women; average age 26.8 yrs. The normal controls were from laboratory personnel and consisted of 4 men and 4 women; average age 25.2 yrs.

The test was carried out in the following manner after obtaining informed consent: the overnight fasting subject first empties his bladder and then he/she is given $6.0 \mathrm{~g} \mathrm{Na}$ benzoate dissolved in about $200 \mathrm{ml}$ of water. The urine is collected for a 4 hour period and determination of hippuric acid immediately carried out. The data are expressed in terms of sodium benzoate.

\section{RESULTS}

The results of this simple test are given in Table 1. It can be seen that the excretion of hippuric acid, expressed as benzoic acid, is markedly decreased in the patients with Friedreich's Ataxia compared to normal control subjects. Only 2 of the patients had concentrations slightly above the lowest value obtained in the controls. It is noteworthy that the only control subject excreting less than $3.0 \mathrm{~g}$ of hippuric acid determined as benzoic acid had suffered from hepatitis 6 months previously. The difference between the two groups was highly significant $(t=5.39, p<0.001)$ by Student's unpaired t test.

\section{DISCUSSION}

The results of the present study, which indicates that hippuric acid is not formed in normal quantity over a 4 hour period following ingestion of $6.0 \mathrm{~g}$ of Sodium benzoate, confirm the preliminary observation made by Bertrand et al, (1982, this issue) in the course of a general profiling of $\alpha$-keto acids in Friedreich's Ataxia. As stated above, hippuric acid is formed from the conjugation of benzoic acid with the amino-acid glycine. This is a two step process: first benzoic acid reacts with coenzyme $\mathrm{A}(\mathrm{CoA})$ in the presence of $\mathrm{Mg}^{++}$, and ATP to be "activated" into

Table 1

4 Hour excretion of hippuric acid rexpressed as benzoic acid) after the ingestion of $6.0 \mathrm{~g}$ sodium benzioate

$\begin{array}{lcc} & \text { Friedreich } & \text { Nonmal Controls } \\ \text { Number } & 12 & 8 \\ \text { Benzoic acid (g) } & 1.55 \pm 0.19^{\star} & 2.99 \pm 0.15 \\ (\text { mean SEM) } & & \\ \text { Range } & 0.60-2.54 & 2.2-3.47 \\ * \mathrm{p}<0.001 & & \end{array}$

benzoyl S CoA by the action of a CoA ligase, probably within the endoplasmic reticulum. This activated benzoylCoA then conjugates with glycine, probably within lysosomes, to give hippuric acid. This step is favoured by an $\mathrm{N}$-acyl transferase, possibly specific for phenolic acids.

The steps described for benzoic acid are essentially similar to those known to regulate the formation of taurocholate and glycocholate: cholic acid, formed from the cholesterol moiety, is first activated in the endoplasmic reticulum by cholate: $\mathrm{CoA}$ ligase (EC 6.2.17) to form the coenzyme thioester cholyl-S-CoA (better called Bile acylCoA to account for activation of the other bile acids). This reaction necessitates $\mathrm{Mg}^{++}$, ATP, CoA, and NAD. The next step of the reaction is catalyzed by the enzyme bile-acidCoA: amino acid $\mathrm{N}$-acyltransferase (EC 2.3.1). Contrary to previous beliefs, Killenberg and Jordan (1978) were able to show that this enzyme is the same for the conjugation of glycine and of taurine, but that its affinity for the respective amino acids probably varies between species. When benzoic acid enters the body it is, in the main, combined with glycine to form hippuric acid, but a fraction of the benzoate is conjugated with glucuronic acid and excreted in the urine. This fraction tends to increase significantly when hippuric acid formation is somewhat impaired.

Conjugation with glucuronic acid relative to glycine increases with large doses of benzoic acid or in the presence of liver disease. Quick's hippuric acid test is thus mainly a measure of the capacity of the liver to synthesize glycine, or of the availability of that amino acid for conjugation. It is also a measure of the enzymatic mechanism (enzyme and co-factors) which unites benzoic acid with aminoacetic acid. All of these variables must be studied before interpretations can be given for our observation of low hippuric acid formation in Friedreich's Ataxia:

a) Availability of substrates. There are two specific substrates for hippuric acid formation: benzoic acid and glycine. Benzoic acid is given in high concentrations (in our study $6.0 \mathrm{~g}$ were given orally), but its concentration within the liver is hypothetical because of the unknowns of intestinal 
absorption and portal transport. In view of the massive dose, we can safely deduce that a significant portion of the load reaches the liver in a bolus of such magnitude that it dwarfs all other substrates that could be available to the enzymes. For its parts, glycine is the most abundant metabolic amino acid present in the liver. It occurs generally in the body and is transported to the liver by the blood from defined pools. A deficiency in glycine as a substrate is hard to imagine, but cannot be ruled out. Indeed glycine concentrations were found to be significantly but minimally decreased in plasma from patients with Friedreich's Ataxia while urine levels were normal (Lemieux et al, 1976). We have no information relating to glycine synthesis in that disorder.

b) Co-factor availability. The availability of two main trace co-factors, $\mathrm{Mg}^{++}$and $\mathrm{NAD}$, has not been specifically studied in Friedreich's Ataxia. However there is some evidence that both $\mathrm{CoA}$ and ATP availability may be somewhat impaired in that disease. Co-enzyme $\mathrm{A}$ is formed in a series of reactions from the free vitamin panthothenic acid. Although determinations of the concentration of that vitamin in Friedreich's Ataxia appeared to be normal, it must be recalled that in swine, panthothenic acid deficiency produces lesions in the dorsal root ganglia and the posterior columns of the cord almost identical to what is seen in Friedreich's Ataxia (see Barbeau, 1979). The evidence in favour of a defect in the availability of ATP, which compound is necessary for the "activation" of benzoic acid, is much stronger. In fact, ATP is the most important known donor of energy in the conjugation reaction. As reviewed by Barbeau (1980), there is a wealth of information indicative of a deficient energy production within the mitochondria in that disorder. The recent polarographic data of Stumpf et al (1982) are also evidence for uncoupled phosphorylation in these patients.

c) Enzyme availability. No data has yet been obtained concerning this important point. However it must be mentioned that total activity of the acyltransferase will be dependant upon product inhibition, on the one hand, and substrate competition, on the other. Concerning this latter point, little of consequence is known. By analogy we can recall that in rats the affinity of the enzyme for taurine is 40 times higher than for glycine (Killenberg and Jordan, 1978). The situation in man has not been examined, but it is known that supplements of glycine will not modify the glycine/taurine $(\mathrm{G} / \mathrm{T})$ ratio of bile acid conjugates, while the slightest addition of dietary taurine will lower significantly the $G / T$ ratio in the bile (Sjovall, 1959; Truswell et al, 1965). Thus a significant increase in taurine availability (from diet, uptake defects, or synthesis) in the liver could tip the conjugation mechanism towards tauroconjugates with a relative decrease in glycine conjugation. It is of great interest that in preliminary experiments with Dr. Claude C. Roy, we were able to show an abnormal G/T ratio in the bile of three ataxic patients (ratio values: 1.5:1, 1.0:1, 1.0:1 respectively as opposed to a normal ratio of $3.2: 1$ ). Thus a relative increase in the formation of tauroconjugates may well be present in Friedreich's Ataxia, and could consequently reduce affinity of the conjugating enzymes for glycine. (Gottfries et al, 1966).

A final possibility exists to account for a postulated increased availability or input of taurine as a substrate in the liver of patients with Friedreich's Ataxia. Evidence reviewed elsewhere in this issue (Barbeau et al, 1982) indicates that taurine is lost in the urine of these patients (possibly through a block in the high affinity taurine reuptake mechanism in the tubules). $70 \%$ of the body taurine stores are in muscles, including the heart, but most of the synthesis of taurine even if minimal in man takes place in the liver, from cysteic acid (for reviews see Huxtable and Barbeau, 1975; Barbeau and Huxtable, 1978). In the face of the postulated muscle deficiency in taurine, and without increased taurine ingestion, it is expected that taurine synthesis would be increased as a compensatory mechanism. This would be even more so if the reuptake defect found in the tubules (see Barbeau et al,
1982 , this issue) were also present in the intestinal wall brush border membrane, thus interfering with the entero-hepatic circulation and reuptake of the tauroconjugates (Hofmann, 1976). In this situation there should be an increase in taurine synthesis in the liver (Gottfries et al, 1966).

With such an increase in local synthesis, the immediate availability of taurine for conjugation in the liver would be greater, again favouring a lowered $\mathrm{G} / \mathrm{T}$ radio (which was indeed observed) and a relative decrease in availability of the enzyme for glycine conjugation, including to benzoic acid during the test.

In conclusion, we have observed a markedly decreased formation of hippuric acid (from benzoic acid plus glycine) in Friedreich's Ataxia. Since tauro-conjugation appears to be normal, or even hyperactive, in these patients, it is unlikely that co-factor or enzyme unavailability are the major culprits. We would tend to regard competition for, or a favoured affinity of the available enzymes for the taurine substrate (due to increased concentrations of taurine as substraste in liver cells, or to changes in affinity constants?) as the probable cause of the relative decrease in glycine conjugation. This would be reflected in impaired hippuric acid formation. At any rate events occurring in the liver should receive much closer attention in the future, in Friedreich's Ataxia. Moreover, to the extent that it is increased in chronic liver disease, urinary taurine may reflect the amount of taurine available for conjugation in the liver. Higher concentrations of taurine in the urine should thus accompany lowered $\mathrm{G} / \mathrm{T}$ ratios in the bile, as was noted in the present study.

\section{ACKNOWLEDGEMENTS}

The studies reported in this paper were supported by grants from l'Association canadienne de l'Ataxie de Friedreich and the $O$. Malette Foundation of the Hôtel-Dieu Hospital. The authors would like to acknowledge the help of Dr. Claude C. Roy for determination of bile G/T ratio, and to thank Miss Suzanne Paris for nursing assistance and Mrs. Hélène L. Crête for typing the manuscript. 


\section{REFERENCES}

BARBEAU, A. (1979) Friedreich's Ataxia 1979: an overview. Can. J. Neurol. Sci. 6: 311-319.

BARBEAU, A. (1980) Friedreich's Ataxia 1980: an overview of the physiopathology. Can. J. Neurol. Sci. 7: 455-468.

BARBEAU, A., BRETON, G., LEMIEUX, B. and BUTTERWORTH, R.F. (1976) Bilirubin Metabolism in Friedreich's Ataxia Preliminary investigation. Can. J. Neurol. Sci. 3: 365-372.

BARBEAU, A., and HUXTABLE, R.J. editors (1978) Taurine and neurological disorders, Raven Press, New York, 1978, pp. 1-468.

BARBEAU, A., PATENAUDE, F., NADON, G., CHARBONNEAU, M. and CLOUTIER, T. (1982) A possible genetic pattern of taurine urinary excretion in Friedreich's Ataxia. Can. J. Neurol. Sci. (This issue).

BERTRAND, M., BOUCHARD, R., GAUTHIER, G.L., BOUCHARD, J.P. and BARBEAU, A. (1982) Quantitative metabolic profiling of $\alpha$-keto acids in Friedreich's Ataxia. Can. J. Neurol. Sci. (This issue)

BOUCHARD, J.P., BARBEAU, A., BOUCHARD, R., PAQUET, $M$. and BOUCHARD, R.W. (1979) A cluster of Friedreich's Ataxia in Rimouski, Quebec. Can. J. Neurol. Sci. 6: 205-208.

CAMPANELLA, G., FILLA, A., DE FALCO, F., MANSI, D., DURIVAGE, A., and
BARBEAU, A. (1980) Friedreich's Ataxia in the south of Italy: A clinical and biochemical survey of 23 patients. Can. J. Neurol. Sci. 7: 351-357.

GEOFFROY, G., BARBEAU, A., BRETON, G., LEMIEUX, B., AUBE, M., LEGER, C., and BOUCHARD, J.B. (1976) Clinical description and Roentgenologic evaluation of patients with Friedreich's Ataxia. Can. J. Neurol. Sci. 3: 279-286.

GOTTFRIES, A., SCHERSTEN, T. and EKDAHL, P.H. (1966) The capacity of human liver homogenates to synthesize taurocholic and glycocholic acid in vitro- an experimental study in patients with presumably normal liver function. Scand. J. Clin. and Lab. Invest. 18: 643-653.

HAMEL, E., BEDARD, D., LAVIOLETTE, F., BUTTERWORTH, R.F. and BARBEAU, A. (1978) Familial hyperbilirubinemia in Friedreich's Ataxia. Can. J. Neurol. Sci. 5:101-105.

HOFMANN, A.F. (1976) The enterohepatic circulation of bile acids inman. Adv. Int. Med. 21:501-534.

HUXTABLE, R. and BARBEAU, A. editors (1976) Taurine, Raven Press, New York, 1976. pp. 1-397.

KILLENGERG, P.G. and JORDAN, J.T. (1978) Purification and characterization of bile acid-CoA: amino acid N-Acyltransferase from rat liver. J. Biol. Chem. 253: 10051010.
LEMIEUX, B., BARBEAU, A., BERONIADE, V., SHAPCOTT, D., BRETON, G., GEOFFROY, G., and MELANCON, S. (1976) Amino acid metabolism in Friedreich's Ataxia. Can. J. Neurol. Sci. 3: 373-378.

MORGAN, R.O., NAGLIE, G., HORROBIN, D.F. and BARBEAU, A. (1979) Erythrocyte protoporphyrin levels in patients with Friedreich's and other ataxias. Can. J. Neurol. Sci. 6: 227-232.

QUICK, A.J. (1936) Clinical value of test for hippuric acid in cases of diseases of liver. Arch. Int. Med. 57: 544.

SJOVALL, J. (1959) Dietary glycine and taurine in bile acid conjugation in man. Proc. soc. exp. Biol. 100b; 676-678.

STUMPF, D.A., PARKS, J.K., EGUREN, L.A. and HAAS, R. (1982) Friedreich's Ataxia: III. Mitochondrial malic enzyme deficiency. Neurology (Ny) 32: 221-227.

TRUSWELL, A.S., McVEIGH, S., MITCHELL, W.D. and BRONTESTEW ART, B. (1965) Effect in man of feeding taurine on bile acid conjugates and serum cholesterol levels. J. Atheroscler. Res. 5: 526-532.

WALKER, J.L., CHAMBERLAIN, S. and ROBINSON, N. (1980) Lipids and lipoproteins in Friedreich's Ataxia. J. Neurol. Neurosurg. Psychiat. 43: 111-117.

WEICHSELBAUM, T.E., PROBSTEIN, J.G. (1938) Determination of hippuric acid in urine. J. Lab. Clin. Med. 24: 636-639. 